\title{
Intractable Diarrhoea due to Congenital Enterocyte Defects
}

\author{
Alan D. Phillips \\ Centre for Paediatric Gastroenterology, Royal Free Hospital, London, UK
}

\section{Key Words}

Intractable diarrhoea $\cdot$ Infancy $\cdot$ Enteropathy

\begin{abstract}
Background: Intractable diarrhoea of infancy represents a severe problem with a high degree of morbidity and mortality. These cases demand dedicated care from both parents and medical staff as there are no easy remedies. The rarity of patients indicates that progress in understanding these disorders requires concerted international efforts to pool resources and patients. Regular reviews of publications in the field are required to disseminate advances and to air hypotheses and diagnostic criteria. Methods: This is a review of current and previous literature on congenital enterocyte defects. Results: Discrete diagnoses are possible within this syndrome, and diagnostic criteria are becoming accepted. Cases are being reported on a world-wide basis, and differences in clinical course are becoming apparent with amelioration of severity in some instances. However, a high level of morbidity and mortality remains. Conclusions: There is still a long way to go in determining the underlying basis of the disorders. However, the promise of determining the genetic basis of the diseases is becoming a reality as
\end{abstract}

molecular genetic analyses are performed. This is a priority as it should afford clearer diagnostic criteria, clarify disease relationships and give much need pathogenic information.

\section{Copyright @ 2006 Nestec Ltd., Vevey/S. Karger AG, Basel}

\section{Introduction}

Intractable diarrhoea remains a severe paediatric problem with a high degree of morbidity and mortality. It represents a spectacular individual burden that defies treatment. It demands committed care from both parents and medical staff. This particular course of intractable diarrhoea, i.e. congenital enterocyte defects, often affects young infants in the first days of life. Complexities that relate to tissue and venous access for diagnosis and treatment add significantly to the problems presented by diarrhoeal losses that can amount to $10 \%$ or more of body weight per day. Nevertheless, discrete diagnoses are possible. Parenteral nutrition has allowed relatively longterm survival to occur; intestinal transplantation offers hopes for a disease-free existence, and molecular genetics is being applied in an attempt to unravel the gene defects that surely lie at the basis of the disease.

\section{KARGER \\ Fax +41613061234 E-Mail karger@karger.ch} www.karger.com
C 2006 Nestec Ltd., Vevey/S. Karger AG, Basel 0517-8606/06/0641-0015\$23.50/0

Accessible online at:

www.karger.com/ane
Alan D. Phillips, PhD

Centre for Paediatric Gastroenterology

Lower 3rd Floor, Royal Free Hospital, Pond Street

London, NW3 2QG (UK)

Tel. +44 207830 2783, Fax +44 207830 2146, E-Mail a.phillips@medsch.ucl.ac.uk 

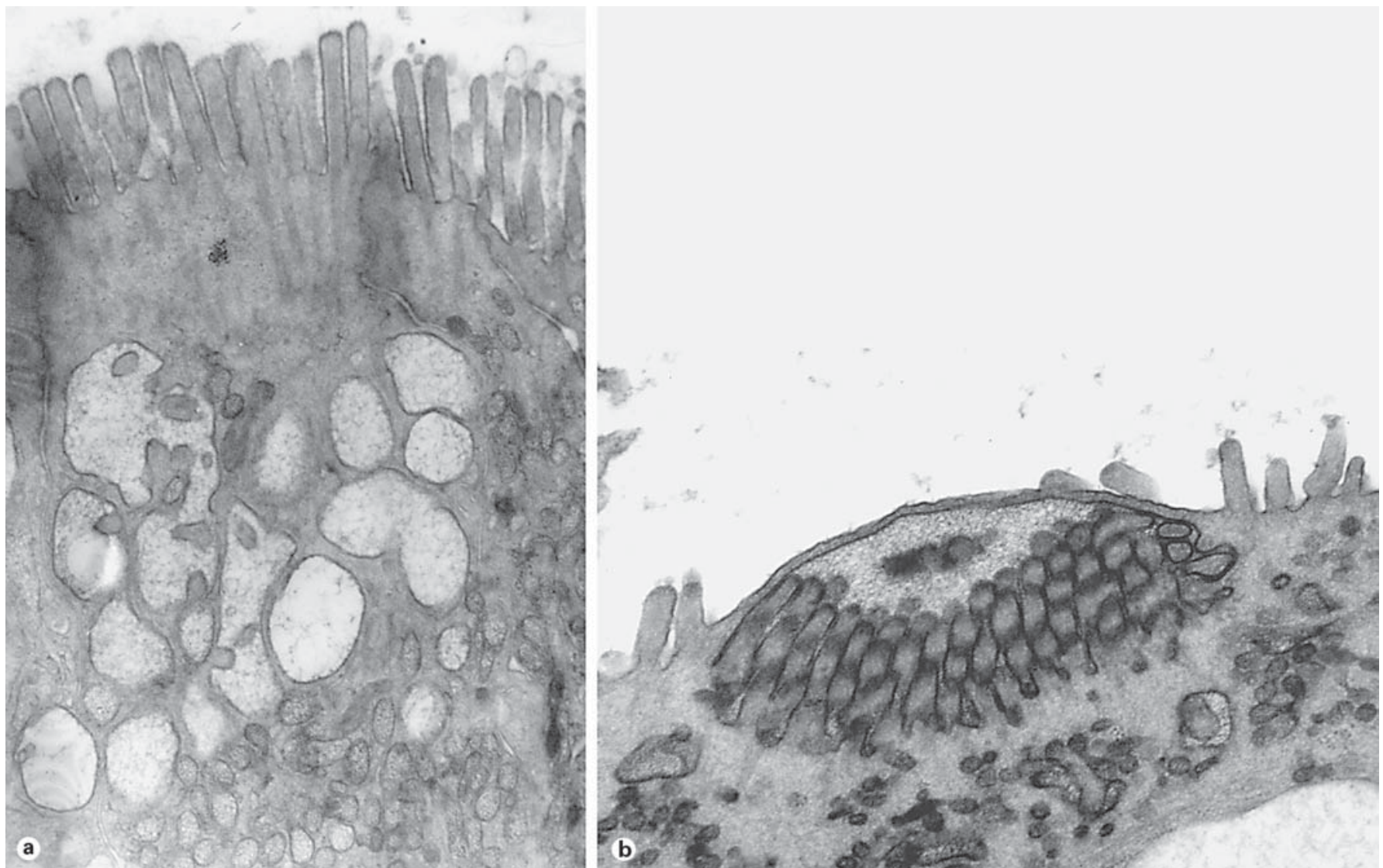

Fig. 1. Microvillous atrophy. a Apparent development of microvilli within a cell with an intact, although short, brush border. b Blister-like microvillous inclusion, appearance of engulfment.

The term intractable diarrhoea was introduced by Avery et al. [1] in the early 1960s. A group of 20 children $<3$ months of age with chronic diarrhoea (more than 14 days duration), negative stool cultures, and persistent diarrhoea despite medical interventions were studied. All required parenteral nutrition and 9 died. Similar reports were made in the following years [2, 3] with the suggestions that the condition was inherited, involved intestinal damage, and that more than one disease entity was probably responsible (familial enteropathy [4] and lethal familial protracted diarrhoea [5]).

Davidson et al. [4] described the enteropathy as crypt hypoplastic villous atrophy without lamina propria inflammation, indicating that crypt hyperplasia (as seen in celiac disease) and an immune-mediated component were not evident. Whilst later studies have questioned the hypoplastic nature of the enteropathy (see below), this observation was taken further and immunohistological criteria were applied to cases of intractable diarrhoea [6, 7]. This approach allowed a division between immunemediated and epithelial-based diseases, such that disease categories have been clarified [7] and optimisation of treatment options has been proposed [8]. This paper will concentrate on epithelial-based defects and will not consider autoimmune enteropathy and related immune-mediated disorders or therapeutic options, as these are covered elsewhere.

Idiopathic ulcerating enterocolitis of infancy $[9,10]$ also is not considered, as its features are more like intractable diarrhoea with an immune basis.

To date a small number of discrete diagnoses have been recognised within the heading of congenital enterocyte defects associated with intractable diarrhoea. The level of evidence for placing them in this category is variable, but at the minimum there is an enteropathy and no, or slight, inflammation in the lamina propria. The un- 

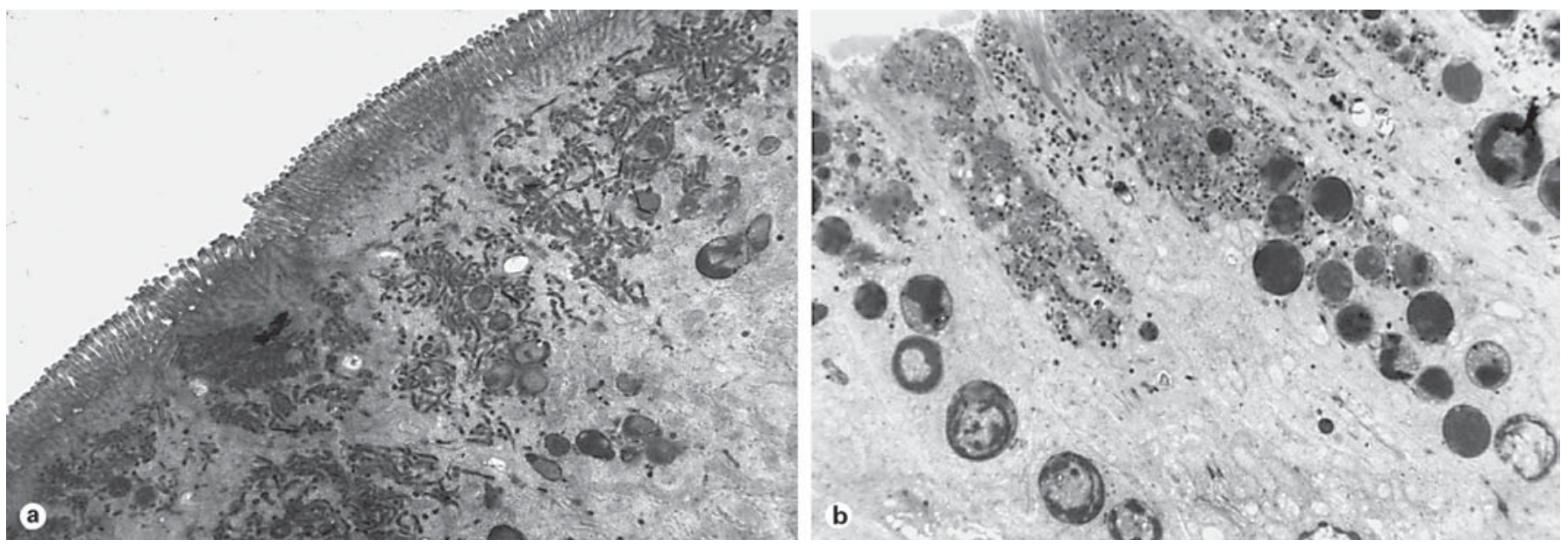

Fig. 2. Microvillous atrophy. Secretory granules in late onset (a) and atypical cases (b).

derlying abnormalities in these conditions have not been established and work is underway to establish their molecular genetic bases. No gene defects have yet been discovered. Diagnoses include microvillous atrophy or microvillus inclusion disease, tufting enteropathy or epithelial dysplasia, syndromatic diarrhoea or trichohepatic-enteric syndrome, idiopathic ulcerating enterocolitis of infancy, and disorders of glycosylation, although idiopathic cases also remain. These are considered in turn below. Several review articles have been published concerning the more common diagnoses within the intractable diarrhoea of infancy syndrome [7, 9-15] and this review will attempt to avoid too much repetition.

\section{Microvillous Atrophy/Microvillus Inclusion Disease}

In 1982 at the ESPGHAN annual meeting in Madrid two abstracts were presented that highlighted bizarre findings in the epithelium of infants with intractable diarrhoea. Schmitz et al. [16] coined the term, microvillous atrophy, whereas Goutet et al. [17] referred to Davidson et al. [4] with the descriptive term, familial enteropathy with hypoplastic villous atrophy. Both described the finding of microvillous inclusions within the epithelium, which had been described by Davidson et al. [4] in one of their series of 5 infants; they additionally reported the presence of 'secretory granules' in crypt cells and surface enterocytes [4]. We published 2 more cases of intractable diarrhoea of congenital onset exhibiting an enteropathy with the same distinguishing features (i.e. microvillous inclusions and increased 'secretory granules'; fig. 1,2) and suggested that these were diagnostic characteristics of the disease [18]. Subsequently Cutz et al. [11] suggested the term, microvillus inclusion disease, in order to highlight the microvillous abnormality.

\section{Clinical Details}

The clinical details are well described and accepted to be severe with onset generally occurring in the first week of life $[4,11,12,18]$. Diarrhoea continues in the absence of enteral feeding and is exacerbated by oral feeding [12]. There appears to be a world-wide distribution of the disease with cases reported from Europe [12], the Middle East [12], Asia [19, 20], and North America [11] including native Americans (Navajo nation) [21]. There are few reports from Africa, although the author has confirmed the diagnosis of microvillous atrophy in a North American of African descent. In developing countries, the severity of the illness may preclude its diagnosis.

The majority of cases present in the first week of life, however in some cases onset of symptoms is after the neonatal period and these have been referred to as 'late onset' microvillous atrophy [12]. The characteristic intestinal morphological abnormalities are present, although with subtle differences (see below), hence the diagnosis. There are few long-term survivors with the disease, although it is considered that 'late onset' cases may have a better prognosis [12]. It is too early to accept this possibility, although in a series of 23 cases, 3 of 5 survivors were 'late onset' [12]. Case 9 in this series is now 23 years old 
and is doing relatively well on partial parenteral nutrition, but without evidence of improvement in his intestinal abnormality (Ventura A, personal commun.).

As more cases have been diagnosed a wider range of presentation and management courses have been described. These are of interest as they may throw light on the underlying pathogenesis and/or serve as reminders to consider the diagnosis in situations outside accepted dogma, although the majority of cases present as described in the literature $[4,11,12,18]$. Most cases are not associated with maternal polyhydramnios, however a case was reported recently with polyhydramnios and apparent antenatal bowel obstruction who turned out to have microvillous atrophy [22]. Therefore microvillous atrophy should be considered as part of the differential diagnosis when chloride diarrhoea [23] and $\mathrm{Na}-\mathrm{H}$ exchange deficiency [24] are possible. Another case of 'late onset' (3 months) and characteristic diagnostic findings spontaneously gained weight at 2 years of age, although diarrhoea continued, and she no longer required parenteral nutrition at 4 years of age [25]. Whilst this case represents an unusual course for this disease, early intestinal transplantation [26] would not have been appropriate for this patient, or perhaps for other 'late onset' cases.

Another interesting event occurred in a case waiting for intestinal and liver transplantation [27]. After a liver biopsy he had a severe intraperitoneal bleed requiring surgery; life-threatening haemorrhagic shock developed with renal failure. Coincidently his diarrhoea decreased, he had no stool for 1 week and then output continued at $10-30 \mathrm{ml} / \mathrm{kg} /$ day until transplantation. Enteral feeds produced an increased stool output and there was no change in intestinal morphology. An extreme lowering of hydrostatic pressure, apparently induced a change in the secretory nature of the diarrhoea.

The disease is probably an autosomal recessive trait due to the number of consanguineous parents and the finding of families with affected siblings [12, 28]. Coincident genetic diseases have been described [29, 30], but it is unclear if they represent contiguous gene syndromes or are inherited independently. The high number of consanguineous parents opens the way for molecular genetic studies and the chance of establishing the genetic basis of the disease.

Clinically similar cases of intractable diarrhoea without the diagnostic intestinal features of microvillous atrophy prompted the suggestion that such cases may be related, and are indicative of a spectrum of microvillous disorders [31, 32]. These have been termed intestinal microvillus dystrophy [31]. It is possible that the characteristic diagnostic features have been overlooked [33], and the degree of similarity with microvillous atrophy requires further studies, including molecular genetic analysis.

\section{Pathology}

There is an enteropathy with villous atrophy, but without severe crypt hyperplasia, producing a thin mucosa [12]; lamina propria inflammation is absent. This is not hypoplastic villous atrophy [4], as crypt cell numbers are increased [12, 34], as are apoptosis and proliferation [35]. The lack of crypt cell hyperplasia is not due to a limited crypt ability to respond as epidermal growth factor treatment increases intestinal cell proliferation, but without an improvement in clinical state [34]. Epithelial cell death compromises digestion and absorption and is one reason for the diarrhoeal state.

If the small intestine is stained with periodic acidSchiff (PAS) stain an abnormal accumulation of PASpositive material is seen in the apical cytoplasm of epithelial cells. In congenital microvillous atrophy this occurs in upper crypt epithelium, whereas in 'late onset' cases the accumulation appears in low villous epithelium, and a normal brush border PAS stain is seen in lower cells [12]. In a third variant, termed 'atypical' microvillous atrophy, the PAS abnormality occurs in the low crypt, and towards the surface epithelium some normal brush border PAS staining is observed [12]. The PAS abnormality suggests that a brush border-destined substance accumulates within the cell rather than being transported to the apical membrane. This distribution parallels the electron microscopy (EM) observation of an increase in 'secretory granules'. The two abnormalities likely represent the same phenomenon [36]. Thus, the secretory granules contain material that is positioned normally in the brush border. EM of the 'granules' showed that they were not discrete granules but made up a vesicular network [36]. The Golgi complex was normal indicating a post-Golgi block in exocytosis. The routine PAS gives the opportunity of retrospective diagnosis [36].

EM has demonstrated the other hall mark of microvillus atrophy, the presence of microvillous lined vacuoles, or inclusions, within the apical cytoplasm of surface epithelial cells (fig. 1), i.e. these occur at a later time in the epithelial cell life cycle than do secretory granules. They can occur as small or large inclusions and occasionally appear as invaginations of the apical membrane or as 'blister-like' profiles with microvilli on one side of the inclusion (fig. 1b). Microvillous inclusions undergo lyso- 
somal digestion and autolysosomal bodies may have microvillous fragments in them. In many cases microvilli may be seen on lateral epithelial cell membranes.

Microvillous inclusions and an increase in secretory granules have been described in both the small and large bowel [18], but not in the stomach; they have not been described in the renal epithelium or in the liver, but they do appear in the gall bladder epithelium.

The brush border is abnormal in this disease, as indicated by the term microvillous atrophy. However, it must be realised that in congenital microvillous atrophy microvilli appear normal in the crypt region and appear variably short or absent on the villus. In 'late onset' cases normal microvilli appear in the low villous region. In 'atypical' microvillous atrophy microvilli are short or absent on upper crypt cells, and they reappear on surface exposed epithelium. These patterns of microvillous appearance parallel the distribution of secretory granules, i.e. once the granules have appeared the microvilli shorten, and if the secretory granules reduce in number then the microvilli reappear [12].

\section{Diagnosis}

The diagnosis can be readily made with PAS staining and transmission EM of proximal small intestinal mucosal biopsies. The simplest approach is to perform PAS staining on well-orientated formalin-fixed tissue and look for an accumulation of PAS-positive material in the epithelial apical cytoplasm, usually in the upper crypt or low villous region. If this is found then transmission EM should be performed to determine if microvillous inclusions can be seen. These should be present in surface-located epithelial cells, so orientation is important, and difficulties will arise in a cross-sectionally cut sample.

Various staining techniques have been suggested as diagnostic tools, including alkaline phosphatase [37], carcinoembryonic antigen [38] and CD10 antigen [39], to avoid the requirement for EM which, although important [40], is seen as technically demanding. These techniques can demonstrate the presence of microvillous inclusions, rather than the PAS abnormality. There is a better chance of a definitive diagnosis if both abnormalities are considered and there is a danger of misdiagnosis if only histochemical means are employed as positive staining also may be located in autophagosomes.

\section{Pathogenesis}

The disease's pathogenesis is unknown. The presence of microvillous inclusions indicates that there may be a basic disorder of cytoskeletal assembly. However, the finding of normal microvilli in cells in their early stages of development in 'congenital' and 'late onset' cases, and the reappearance of microvilli in 'atypical' cases [12] indicate that this is unlikely. The major microvillous cytoskeletal proteins are present in crypt cell apical cytoplasm providing a source for brush border growth and maintenance [41], and this system may be disturbed leading to premature microvillous construction within the cell (fig. 1a), or inappropriate growth on the lateral cell membrane. Microvillous inclusions may arise by engulfment of apical membrane (fig. 1b) [4, 42]. The uptake of luminal material into microvillous inclusions supports this hypothesis [42]. These possibilities are not notably exclusive.

The prevalence of secretory granules (fig. 2) indicates a defect in exocytosis of brush border destined material. The direct and indirect constitutive pathways of brush border enzymes are intact [43] (although enzyme levels are lowered due to cell damage [12]), implying a defect in an unidentified trafficking route. An early paper reported a brush border myosin deficiency [44] suggesting a defect in actin-myosin interactions responsible for the delivery of membrane associated substances to the brush border [45]. Ameen \& Salas [46] in a single case report, have also suggested an apical membrane trafficing defect.

The nature of the secretory granules is unknown. Normally they occupy $2.5 \%$ of the apical cell volume, whereas in microvillous atrophy it is $40 \%$ [46]. Recent data, demonstrating the presence of acetylated sialic acid and blood group antigens in the secretory granules, indicate they contain glycocalyx-like material, which is blocked from exocytosis [47]. This is supported by the flocculent, fibrillar nature of their content (fig. 1a). The glycocalyx forms a hydrophilic polyanionic gel coat on the cell surface and maintains cell surface charge, protects against physical trauma, and regulates ionic \& macromolecular access [48]. A lack of the glycocalyx would have profound consequences on normal cell function and accumulation of cellular debris within the cell may disrupt normal processes. In utero, the intestine is bathed with amniotic fluid of similar osmolality to serum, resulting in no osmotic pressure across the gut. This changes dramatically after birth and the lack of a functional intestinal glycocalyx could explain the rapid onset of symptoms and why most cases of microvillus atrophy could result from the inability to exocytose the glycocalyx.

Ann Nestlé 2006;64:15-23 


\section{Tufting Enteropathy/Epithelial Dysplasia}

Tufting enteropathy or epithelial dysplasia was described in 3 children by Reifen et al. [50]. Onset of diarrhoea was reported in the neonatal period. One previous case was described by Davidson et al. [4], underlining the variable cause of the intractable diarrhoea in those cases. Feeding dramatically reduced stool volume, and nutritional support allowed a normal growth velocity in 2 cases. The key observation was the presence of an enteropathy exhibiting tufts of closely packed surface enterocytes with rounding of the apical membrane that appeared to be coming away from the epithelium. These were not unique to the condition and were reported in coeliac disease, microvillous atrophy, autoimmune enteropathy and controls, but at a much lower frequency ( 90 vs. $61-<10 \%)$ [50]. Tufting was not seen in the crypt epithelium, there were no distinguishing ultrastructural features, no increase in lamina propria cell infiltration, and the enteropathy persisted despite improvement with nutritional support in 2 cases. This puts this condition into the category of a congenital enterocyte disorder rather than an immunological defect. Similar observations were reported in 6 children [51] with additional data concerning basement membrane abnormalities, i.e. reduced laminin and increased heparan sulphate, but the primary or secondary nature of the abnormalities could not be established. $\mathrm{Pa}$ tey et al. [52] investigated adhesion molecules and found an increased presence of desmoglein, an abnormal distribution of $\alpha_{2} \beta_{1}$ integrin along the crypt-villus axis, and an increased presence of desmosomes. They deduced that there were abnormal cell-cell and cell-matrix interactions and that these were involved in the pathogenesis.

It is generally considered to be an autosomal recessive condition. Consanguineous parents and several affected siblings are common [15]. Although Reifen et al. [50] reported normal colons in their cases, further reports have shown the colon to be affected with some crypt abnormalities (branching and pseudocysts) [52]. Diagnosis is not necessarily easy as the prevalence of tufts appears to vary with time and repeat biopsies are required to establish the diagnosis, along with the definite exclusion of microvillous atrophy [15]. In some cases lamina propria inflammation may be present as a secondary event and treatment can allow increased caloric intake [53]. There is some evidence that the condition may resolve with time. Two adults, following 13-15 years of treatment, are now off parenteral nutrition [53], and there has been a report of a successful pregnancy in a woman with tufting enteropathy [54].
Further clarification of this condition awaits molecular genetic analyses. An association between tufting enteropathy and polymalformations has been described [55], but this may be coincidental rather than genetically linked.

\section{Integrin Deficiency}

Lachaux et al. [56] recently described an infant presenting with pyloric atresia and intractable diarrhoea. Light microscopy showed extensive severe epithelial cell desquamation from the stomach to the rectum, with only crypt epithelial cells remaining in situ. EM of the gut revealed normal desmosomes with separation between the lamina propria and the basal membrane of enterocytes. This disorder is considered to be related to a congenital deficiency of $\alpha_{6} \beta_{4}$ integrin, but of an intestinal isoform, as the cutaneous expression of $\alpha_{6} \beta_{4}$ integrin appeared normal. This integrin is defective in epidermolysis bullosa in which gross epidermal shedding occurs. It is likely that there is a mutation within the intestinal $\alpha_{6} \beta_{4}$ isoform or a deficiency of a related, immunohistochemically cross-reactive, intestinal integrin.

\section{Syndromatic Diarrhoea}

A small number of patients have been described as having syndromatic intractable diarrhoea $[57,58]$. Similar cases have been reported previously, falling within the 'tricho-hepato-enteric' syndrome [59-61]. In this syndrome cases are small-for-gestational age, and have intractable diarrhoea starting in the first months of life, liver disease, facial dysmorphism, mental retardation and abnormal hair. Small intestinal morphology is variably abnormal ranging from severe villous atrophy to minor villous shortening. Colitis also has been reported [57]. Consanguineous parents are common [58] and sibs with the syndrome have been described $[59,61]$ suggesting an autosomal recessive condition. Some cases have evidence of immunodeficiency with poor responses to vaccination and hypogammaglobulinaemia.

Prognosis appears to be variable; some cases have succumbed to infection or liver disease, others require total or partial parenteral nutrition, and one case is on oral feeds [58]. Tolerance to enteral feeds was suggested to be related to the state of the small intestine [58]. The relationship between syndromatic intractable diarrhoea and 'tricho-hepato-enteric' syndrome needs to be evaluated 
further. The clinical pattern suggests either mutation within several genes, inherited together by linkage disequilibrium, or interference with a higher level of control, such as a patterning gene; as relatively few patterning genes have been implicated in hair development, this may allow a more focused search for candidate mutations [15].

\section{Congenital Disorders of Glycosylation and Protein-Losing Enteropathy}

Diarrhoea has been associated variably with congenital disorders of glycosylation and one report described severe intractable diarrhoea at 2 weeks of age as a presenting symptom that persisted on parenteral nutrition with profound hypoalbuminaemia [62]. Neurological symptoms developed, there was no response to mannoses treatment and the patient died at 24 months of age from hepatic insufficiency. The basic defect of glycosylation, beyond a type- 1 defect, could not be identified.

Three similar cases with intractable diarrhoea and severe protein-losing enteropathy have been reported [63]. In these cases the small intestinal mucosa appeared histologically normal, but there was an absence of heparan sulphate on the lateral epithelial cell membranes. The link between heparan sulphate, protein-losing enteropathy and inflammation was established recently experimentally [64]. All required total parenteral nutrition, although diarrhoea persisted. No neurological abnormalities or other signs of glycosylation defect syndrome were described, although a case of congenital disorder of glycosylation type $1 \mathrm{c}$ with severe hypoalbuminaemia and a similar absence of intestinal epithelial heparan sulphate was reported [65], and patients with type- $1 \mathrm{~b}$ congenital disorders of glycosylation have severe diarrhoea and protein-losing enteropathy [66], so there may be similarities between the various conditions.

\section{Other Causes and Summary}

Despite the intensive investigation of cases of intractable diarrhoea many cases remain in which the search for characteristic diagnostic features is elusive. Hopeful$l y$, as the genetic basis of diseases with distinguishing features is discovered, light may be thrown on aspects of these idiopathic conditions. Certainly, the dedication of paediatric gastroenterology teams caring for these children with disorders of enterocyte development has brought about avenues of management and discrete diagnoses that have allowed focussed and productive research. Nevertheless, diarrhoeas and enteropathies due to congenital diseases of enterocyte defects often persist despite medical intervention unless the gut is transplanted. The possibilities of resolution of these demanding and severe illnesses must surely wait for successful gene therapies.

\section{References}

-1 Avery GB, Villavicencio O, Lilly JR, Randolph JG: Intractable diarrhoea in early infancy. Pediatrics 1968;41:712-722.

-2 Larcher VF, Shepherd R, Francis DEM, Harries JT: Protracted diarrhoea in infancy. Analysis of 82 cases with particular reference to diagnosis and management. Arch Dis Child 1977;52:597-605.

3 Hyman CJ, Reiter J, Rodnan J, Drash AL: Parenteral and oral alimentation in the treatment of the nonspecific protracted diarrheal syndrome of infancy. J Pediatr 1971;78:17-29.

4 Davidson GP, Cutz E, Hamilton JR, Gall DG: Familial enteropathy: a syndrome of protracted diarrhea from birth, failure to thrive, and hypoplastic villous atrophy. Gastroenterology 1978;75:783-790.

$\checkmark 5$ Candy DCA, Larcher VF, Cameron DJS, et al: Lethal familial protracted diarrhoea. Arch Dis Child 1981;56:15-23.
$>$ fication of intractable diarrhea in infancy using clinical and immunohistological criteria. Gastroenterology 1990;99:1037-1043.

$>7$ Goulet OJ, Brousse N, Canioni D, WalkerSmith JA, Schmitz J, Phillips AD: Syndrome of intractable diarrhoea with persistent villous atrophy in early childhood: a clinicopathological survey of 47 cases. J Pediatr Gastroenterol Nutr 1998;26:151-161.

$\checkmark 8$ Goulet O, Ruemmele F, Lacaille F, Colomb V: Irreversible intestinal failure. J Pediatr Gastroenterol Nutr 2004;38:250-269.

-9 Sanderson IR, Risdon RA, Walker-Smith JA: Intractable ulcerating enterocolitis of infancy. Arch Dis Child 1991;66:295-299.

10 Thapar N, Shah N, Ramsay AD, Lindley KJ, Milla PJ: Long-term outcome of intractable ulcerating enterocolitis of infancy. J Pediatr Gastroenterol Nutr 2005;40:582-588.
11 Cutz E, Rhoads JM, Drumm B, Sherman PM, Durie PR, Forstner GG: Microvillus inclusion disease: an inherited defect of brush-border assembly and differentiation. N Engl J Med 1989; 320:646-651.

12 Phillips AD, Schmitz J: Familial microvillous atrophy: a clinicopathological survey of 23 cases. J Pediatr Gastroenterol Nutr 1992;14: 380-396.

13 Cutz E, Sherman PM, Davidson GP: Enteropathies associated with protracted diarrhea of infancy: clinicopathological features, cellular and molecular mechanisms. Pediatr Pathol Lab Med 1997; 17:335-368.

14 Sherman PM, Mitchell DJ, Cutz E: Neonatal enteropathies: defining the causes of protracted diarrhea of infancy. J Pediatr Gastroenterol Nutr 2004;38:16-26. 
15 Goulet O, Phillips AD: Congenital enteropathy involving intestinal mucosa development; in Walker WA, Goulet O, Kleinman RE, Sanderson IR, Sherman P, Shneider B (eds): Paediatric Gastrointestinal Disease. Burlington, Decker, 2004, pp 922-931.

16 Schmitz J, Ginies JL, Arnaud-Battandier F, et al: Congenital microvillous atrophy: a rare cause of neonatal intractable diarrhoea. Pediatr Res 1982;16:1014.

17 Goutet JM, Boccon-Gibod L, Chatelet F, Ploussard JP, Navarro J, Polonovski Cl: Familial protracted diarrhoea with hypoplastic villous atrophy: report of two cases. Pediatr Res 1982;16:1045.

$\checkmark 18$ Phillips AD, Jenkins P, Raafat F, WalkerSmith JA: Congenital microvillous atrophy: specific diagnostic features. Arch Dis Child 1985;60:135-140.

-19 Beck NS, Chang YS, Kang IS, Park WS, Lee HJ, Suh YL: Microvillus inclusion disease in two Korean infants. J Korean Med Sci 1997; 12:452-456.

-20 Kaneko K, Shimizu T, Fujiwara S, Igarashi J, Ohtomo Y, Yamashiro Y: Microvillous inclusion disease in Japan. J Pediatr 1999;135: 400.

-21 Pohl JF, Shub MD, Trevelline EE, et al: A cluster of microvillous inclusion disease in the $\mathrm{Na}$ vajo population. J Pediatr 1999;134:103106.

-22 Kennea N, Norbury R, Anderson G, Tekay A: Congenital microvillous inclusion disease presenting as antenatal bowel obstruction. Ultrasound Obstet Gynecol 2001;17:172-174.

-23 Makela S, Kere J, Holmberg C, Hoglund P: SLC26A3 mutations in congenital chloride diarrhea. Hum Mutat 2002;20:425-438.

-24 Keller KM, Wirth S, Baumann W, Sule D, Booth IW: Defective jejunal brush border membrane sodium/proton exchange in association with lethal familial protracted diarrhoea. Gut 1990;31:1156-1158.

$\checkmark 25$ Croft NM, Howatson AG, Ling SC, Nairn L, Evans TJ, Weaver LT: Microvillous inclusion disease: an evolving condition. J Pediatr Gastroenterol Nutr 2000;31:185-189.

26 Ruemmele FM, Jan D, Lacaille F, et al: New perspectives for children with microvillous inclusion disease: early small bowel transplantation. Transplantation 2004; 77:1024-1028.

$\checkmark 27$ Randak C, Langnas AN, Kaufman SS, et al: Pretransplant management and small bowelliver transplantation in an infant with microvillus inclusion disease. J Pediatr Gastroenterol Nutr 1998;27:333-337.

-28 Nathavitharana KA, Green NJ, Raafat F, Booth IW: Siblings with microvillous inclusion disease. Arch Dis Child 1994;71:71-73.

-29 Assmann B, Hoffmann GF, Wagner L, et al: Dihydropyrimidinase deficiency and congenital microvillous atrophy: coincidence or genetic relation? J Inherit Metab Dis 1997;20:681688
30 Heinz-Erian P, Schmidt H, Le Merrer M, Phillips AD, Kiess W, Hadorn HB: Congenital microvillus atrophy in a girl with autosomal dominant hypochondroplasia. J Pediatr Gastroenterol Nutr 1999;28:203-205.

31 Raafat F, Green NJ, Nathavitharana KA, Booth IW: Intestinal microvillous dystrophy: a variant of microvillous inclusion disease or a new entity? Hum Pathol 1994;25:1243-1248.

32 Mierau GW, Wills EJ, Wyatt-Ashmead J, Hoffenberg EJ, Cutz E: Microvillous inclusion disease: report of a case with atypical features. Ultrastruct Pathol 2001;25:517-521.

-33 Weeks DA, Zuppan CW, Malott RL, Mierau GW: Microvillous inclusion disease with abundant vermiform, electron-lucent vesicles. U1trastruct Pathol 2003;27:337-340.

34 Walker-Smith JA, Phillips AD, Walford N, et al: Intravenous epidermal growth factor/urogastrone increases small intestinal cell proliferation in congenital microvillous atrophy. Lancet 1985;ii:1239-1240.

35 Groisman GM, Sabo E, Meir A, Polak-Charcon $\mathrm{S}$ : Enterocyte apoptosis and proliferation are increased in microvillous inclusion disease (familial microvillous atrophy). Hum Pathol 2000;31:1404-1410.

36 Phillips AD, Szafranski M, Man LY, Wall WJ: Periodic acid-Schiff staining abnormality in microvillous atrophy: photometric and ultrastructural studies. J Pediatr Gastroenterol Nutr 2000;30:34-42.

37 Lake BD: Microvillus inclusion disease: specific diagnostic features shown by alkaline phosphatase histochemistry. J Clin Pathol 1988;41:880-882.

38 Groisman GM, Ben-Izhak O, Schwersenz A, Berant M, Fyffe B: The value of polyclonal carcinoembryonic antigen immunostaining in the diagnosis of microvillus inclusion disease. Hum Pathol 1993;24:1232-1237.

39 Groisman GM, Amar M, Livne E: CD10: a valuable tool for the light microscopic diagnosis of microvillous inclusion disease (familial microvillous atrophy). Am J Surg Pathol 2002 26:902-907.

40 Bell SW, Kerner JA, Sibley RK: Microvillous inclusion disease. The importance of electron microscopy for diagnosis. Am J Surg Pathol 1991;15:1157-1164

41 Fath KR, Obenauf SD, Burgess DR: Cytoskeletal protein and mRNA accumulation during brush border formation in adult chicken enterocytes. Development 1990;109:449-459.

42 Reinshagen K, Naim HY, Zimmer KP: Autophagocytosis of the apical membrane in microvillus inclusion disease. Gut 2002;51:514521.

43 Phillips AD, Fransen JAM, Hauri HP, Sterchi E: The constitutive exocytotic pathway in microvillous atrophy. J Pediatr Gastroenterol Nutr 1993; 17:239-246.

44 Carruthers L, Phillips AD, Dourmashkin R, Walker-Smith JA: Biochemical abnormality in brush border membrane protein of a patient with congenital microvillous atrophy. J Pediatr Gastroenterol Nutr 1985;4:902-907.
45 Fath KR, Trimbur GM, Burgess DR: Molecular motors are differentially distributed on Golgi membranes from polarized epithelial cells. J Cell Biol 1994;126:661-675.

46 Ameen NA, Salas PJ: Microvillus inclusion disease: a genetic defect affecting apical membrane protein traffic in intestinal epithelium. Traffic 2000; 1:76-83.

47 Phillips AD, Brown A, Hicks S, et al: Acetylated sialic acid residues and blood group antigens localise within the epithelium in microvillous atrophy indicating internal accumulation of the glycocalyx. Gut 2004;53:1764-1771.

48 Gupta BL: The relationship of mucoid substances and ion and water transport, with new data on intestinal goblet cells and a model for gastric secretion. Symp Soc Exp Biol 1989;43: 81-110.

49 Gillibrand PN: Changes in the electrolytes, urea and osmolality of the amniotic fluid with advancing pregnancy. J Obstet Gynaecol $\mathrm{Br}$ Commonw 1969;76:898-905.

50 Reifen RM, Cutz E, Griffiths AM, Ngan BY, Sherman PM: Tufting enteropathy: a newly recognized clinicopathological entity associated with refractory diarrhea in infants. J Pediatr Gastroenterol Nutr 1994;18:379-385.

51 Goulet O, Kedinger M, Brousse N, et al: Intractable diarrhea of infancy with epithelial and basement membrane abnormalities. J Pediatr 1995; 127:212-219.

$\checkmark 52$ Patey N, Scoazec JY, Cuenod-Jabri B, et al: Distribution of cell adhesion molecules in infants with intestinal epithelial dysplasia (tufting enteropathy). Gastroenterology 1997;113: 833-843.

53 Schaeppi M, Shah NF, Long S, et al: Tufting enteropathy also affects the colon. J Pediatr Gastroenterol Nutr 1999;28:569.

54 Cameron DJ, Barnes GL: Successful pregnancy outcome in tufting enteropathy. J Pediatr Gastroenterol Nutr 2003;36:158.

55 Abely M, Hankard GF, Hugot JP, Cezard JP, Peuchmaur M, Navarro J: Intractable infant diarrhea with epithelial dysplasia associated with polymalformation. J Pediatr Gastroenterol Nutr 1998;27:348-352.

-56 Lachaux A, Bouvier R, Loras-Duclaux I, Chappuis JP, Meneguzzi G, Ortonne JP: Isolated deficient alpha6beta4 integrin expression in the gut associated with intractable diarrhea. J Pediatr Gastroenterol Nutr 1999;29:395401.

57 Girault D, Goulet O, Le Deist F, et al: Intractable infant diarrhea associated with phenotypic abnormalities and immunodeficiency. J Pediatr 1994; 125:36-42.

58 Martinez-Vinson C, Goulet O, Berrebi D, et al: Syndromatic diarrhea in children. Report of 8 cases. J Pediatr Gastroenterol Nutr 2005;40: 651 
59 Verloes A, Lombet J, Lambert Y, et al: Trichohepato-enteric syndrome: further delineation of a distinct syndrome with neonatal hemochromatosis phenotype, intractable diarrhea, and hair anomalies. Am J Med Genet 1997;68: 391-395.

-60 Landers MC, Schroeder TM: Intractable diarrhea of infancy with facial dysmorphism, trichorrhexis nodosa, and cirrhosis. Pediatr Dermatol 2003;20:432-435.

61 Stankler L, Lloyd D, Pollitt RJ, Gray ES, Thom $\mathrm{H}$, Russell G: Unexplained diarrhoea and failure to thrive in 2 siblings with unusual facies and abnormal scalp hair shafts: a new syndrome. Arch Dis Child 1982;57:212-216.
62 Mention K, Michaud L, Dobbelaere D, Guimber D, Gottrand F, Turck D: Neonatal severe intractable diarrhoea as the presenting manifestation of an unclassified congenital disorder of glycosylation (CDG-x). Arch Dis Child Fetal Neonatal Ed 2001;85:F217-F219.

63 Murch SH, Winyard PJ, Koletzko S, et al: Congenital enterocyte heparan sulphate deficiency with massive albumin loss, secretory diarrhoea, and malnutrition. Lancet 1996;347: 1299-1301.
64 Bode L, Eklund EA, Murch S, Freeze HH: Heparan sulfate depletion amplifies TNF-alpha-induced protein leakage in an in vitro model of protein-losing enteropathy. Am J Physiol Gastrointest Liver Physiol 2005;288: G1015-G1023.

65 Westphal V, Murch S, Kim S, et al: Reduced heparan sulfate accumulation in enterocytes contributes to protein-losing enteropathy in a congenital disorder of glycosylation. Am J Pathol 2000;157:1917-1925.

66 Niehues R, Hasilik M, Alton G, et al: Carbohydrate-deficient glycoprotein syndrome type Ib. Phosphomannose isomerase deficiency and mannose therapy. J Clin Invest 1998;101: 1414-1420. 